\title{
KARSTOLOGY AND THE OPENING OF CAVES DURING MOTORWAY CONSTRUCTION IN THE KARST REGION OF SLOVENIA
}

\author{
Martin KNEZ and Tadej SLABE
}

\begin{abstract}
The nature of karst makes constructing a roadway across karst areas a complex task, which is why karstologists take part in motorway construction across Slovenia's karst. Working with planners, karstologists select the best route on the basis of preliminary research. Then they carry out regular karstological monitoring of the construction, to study newly discovered karst phenomena, mostly caves, and also help builders overcome the challenges of karst in a way that will preserve nature as much as possible. During the recent construction of a section of motorway, more than three hundred caves were encountered within a sixty-kilometre stretch of road. Varied tectonic and lithostratigraphical conditions make it even more difficult to predict the cave locations in advance. Various types of cave reflect the development of the aquifer due to the lowering of the groundwater level and of the karst surface. All caves are explored, and the sediments and flowstone in them studied, in an attempt to preserve the most important ones. Caves are an important part of Slovenia's natural heritage, and research contributes new knowledge about the morphology and development of the karst region. Knowledge of unroofed caves and their traces on the karst surface provides a distinct advantage in planning new road sections. Expertise derived from recent experiences enables these features to be detected on the karst surface before the earth moving begins.
\end{abstract}

KEYWORDS: motorway construction in karst, karstological monitoring, unroofed caves

\section{Introduction}

One of larger projects currently underway in Slovenia is that of linking the country with a system of modern motorways. Practically half of Slovenia is karst, and more than half of its water supply comes from karst aquifers. The karst landscape is sensitive and is also an important part of the Slovenian natural and cultural heritage. A thorough knowledge and great effort are needed to preserve it.

For many years, karstologists have cooperated in planning and constructing motorways in karst regions. For this reason, knowledge of karstology is increasingly being applied during construction, since this knowledge provides comprehensive coverage of the characteristics of different types of karst and provides an understanding of the opening of caves and of karst groundwater flow. This knowledge also makes it possible to protect karst features and groundwater effectively. The wisdom of encouraging cooperation between karstologists and constructors has already been well demonstrated (Knez and Slabe, 2001). 
In the selection of route corridors for motorway and railway construction, attention is given primarily to protecting the integrity of the karst landscape, and recommendations are made for avoiding the more important surface karst phenomena and previously known caves. The karstologists attempt to predict the likely degree of perforation of any individual part of the aquifer. Special attention is paid to the potential influence of construction and the eventual use of the motorways on karst waters. Motorways should therefore be impermeable, such that runoff water from the road is first gathered into oil collectors and cleaned before release onto the karst surface.

During motorway construction karstologists are involved in monitoring the route. Newly discovered karst phenomena, particularly caves, are studied, and advice on their preservation is offered if this is possible given the stage of the construction work. Knowledge from the new discoveries also assists the builders. Numerous new discoveries have been made, related to the formation and development of the karst surface, to the epikarst, and to aquifer perforation.

This article presents details of experiences gained from many years of studying karst phenomena during motorway construction. In the authors' opinion, certain known karst phenomena have received too little attention in the past. Attention is focused on examples in Slovenia's Kras region, the "Classical Karst", which gave its name worldwide to landscapes formed from carbonate rock (Kranjc et al., 1997; 1999).

\section{The Classical Karst}

Kras is a region that rises above the northwesternmost part of the Adriatic Sea. It covers the area stretching from the Vipava Valley in the northeast and the FriuliVenezia Giulia lowlands with the Soča River area in the northwest, to the Adriatic Sea in the southwest. To the southeast it is bordered by an extensive area of flysch, with altitudes greater than $600 \mathrm{~m}$, from which surface water flow creates typical and extensive contact karst at the junction with the carbonate rock.

Broadly speaking the 200 to $500 \mathrm{~m}$-high Kras plateau, with a total area of $440 \mathrm{~km}^{2}$, belongs to the Outer Dinarids, and is more specifically a part of the Trieste-Komen synclinorium. From the point of view of tectonic plate theory it lies on the deformed northern edge of the Adriatic plate and is a product of overlap tectonics. Only Cretaceous and Paleogene rocks are found here, including an outstanding variety of limestones that originated largely in shallow sediment basins with abundant flora and fauna.

The surveys discussed here found no evidence of the surface water flows that were used in the past to explain the development of the plateau. Whereas water initially flowed at shallow depth or just along the surface, and vertical percolation was minimal, the groundwater later dropped several hundred meters below the karst surface.

Today there are no surface waters in Kras. All the karst rivers disappear underground at the points where they run from flysch onto limestone bedrock. Underground water flows toward the sources of the Timava River in Italy. The largest stream is the Reka River, which sinks underground in the Skocjan Caves. Some 65\% of the water, however, percolates through the surface in a dispersed and diffuse pattern. From the ecological point of view, Kras is one of the most vulnerable natural systems in Slovenia. 


\section{Planning}

Wherever building is carried out in Kras, numerous karst phenomena are encountered, including dolines and filled or empty karst caves, as segments of old or recent drainage courses through the karst. High quality karstological studies are vital to the safe development of this largely unpredictable karst world. A thorough examination of the terrain where a new transportation route is planned makes choosing the best choice of a route corridor possible and, at the same time, is one of the fundamental starting points for planning construction in this unique and sensitive landscape. In planning motorways from the karstological viewpoint, karstologists therefore evaluate the karst surface, the karst underground and the hydrological features, and weigh the possibilities. Denudation has exposed numerous caves and these can be identified on the karst surface. Recently, special attention has been devoted to unroofed caves discovered during actual motorway construction.

Normally karstologists will initially gather information on karst phenomena with the help of published literature, archives and various collections. Later, the criteria for mapping the line of a selected route are determined with the help of a field survey. In the field, important rock sections are evaluated from the karstological viewpoint. The known entrances of karst caves are shown thematically on maps and augmented with the sits of possible new ones. A projection of subterranean cavities is made, based on surface maps and a genetic interpretation of the morphology and relief of visible denuded caves. If necessary, the possibilities for dumping excess material are also considered, on the basis of the surface maps.

Experience indicates that any route corridor crossing the karst will encounter caves and remnants of cave systems. To avoid potentially numerous unpleasant surprises, the degree of perforation of the karst is examined as thoroughly as possible before the work begins. The most common way to determine details of caves and their locations is by drilling, although drilling cannot provide for comprehensive information about caves. Along with normally measured parameters, drilling helps to determine the type of fill present, if any (e.g. flowstone, alluvium, etc). The shape, type, and frequency of caves in neighbouring areas can be partially predicted by interpolation of known surface and subterranean phenomena. Geo-electric methods have generally not provided satisfactory results in Slovenia, since this methodology normally detects only unroofed caves. Similar results have been recorded using georadar, since interpretation of subterranean cavities that have been crushed or filled with various sediments has been uncertain. The geomorphological approach of examining currently known phenomena has proven more productive.

In the field, the reliability of known data about caves is checked and augmented with new measurements and genetic interpretations. With better information, the karstologists can present a current picture of aquifer perforation and produce predictive subterranean maps.

Due to the specific properties of carbonate rock, the surface waters that percolate into the ground in the areas studied find direct routes to the underground karst aquifer without difficulty. Measurements have shown that water can percolate through a 100 m-thick rock sequence in an hour. Although flysch rock — which in the Kras region lies in uninterrupted direct contact with carbonate rock - is commonly described as a totally impermeable stratum, it should be emphasized that flysch (in 
some places not very thick) occurs merely as isolated lenses on permeable carbonate rocks. Furthermore, it is also recognized that, although they are less numerous, subterranean conduits also form in flysch rock and that rain falling on flysch flows into the karst. Hydrological mapping is therefore also done in the field, to demarcate and determine the basic features of hydrogeological units in the general area of the proposed route corridor, to list hydrological objects, and to determine the physical and chemical properties of springs. If necessary, tracing experiments are carried out during high and low water periods, primarily to determine the direction and speed of underground flow in the neighbourhood of the corridor. The karstologists draw hydrogeological charts and upgrade existing charts with the results of mapping and tracing experiments in the field, make an inventory of the state of the environment, and assess the potential influence of construction on karst waters.

The fundamental guidelines for planning transportation routes can be summarized in a few lines. A route corridor is selected on the basis of a comprehensive evaluation of the karst, with an emphasis on local characteristics. The final route selected will be designed to avoid unique individual karst phenomena, wherever possible. Since more than half of Slovenia's drinking water comes from karst springs, one of the planning priorities is the preservation of karst aquifers.

\section{Karstological monitoring of construction and the opening of caves}

Construction in karst regions is greatly influenced by the degree of perforation of the karst. More than three hundred new caves were discovered along sixty kilometres of motorway constructed in Kras in recent years (Fig.1). Removing soil and vegetation from the karst surface and, of course, major earthworks during digging cuttings and tunnels, exposed surface, epikarst, and subterranean karst phenomena. New discoveries are helping builders learn how to overcome obstacles to construction.

The area studied is dissected by dolines and unroofed caves. Some dolines are more and some less distinctly filled with soil that must be removed. Cracks and shafts are thus opened on their floors and slopes. The floors are reinforced with vaulted sloping rock since the mouths of shafts are commonly smaller than the caves below them, and the dolines are then filled with layers of rubble.

Epikarst is criss-crossed with cracks, which are particularly distinctive and large in Cretaceous limestone. Most are filled with soil, and their walls are dissected by subcutaneous rock forms. As a result of the lowering of the karst surface, a great number of shafts lie immediately below the surface.

Almost one third of newly discovered caves are unroofed caves (Fig.2). These are old caves that became exposed due to the lowering of the karst surface and no longer have the upper part of their walls and ceiling. They are an increasingly recognizable phenomenon on the surface. The shape of an unroofed cave is a consequence of the type and shape of the original cave and the development of the karst aquifer and its surface in various geological, geomorphological, climate, and hydrological conditions. However, how distinctly the surface form of an unroofed cave appears to be dictated by the speed at which the alluvium was washed out of the cave compared with the lowering of the surrounding surface. If the speed was low, soil and vegetation, or areas of alluvium and flowstone, are visible on the surface; where it was 


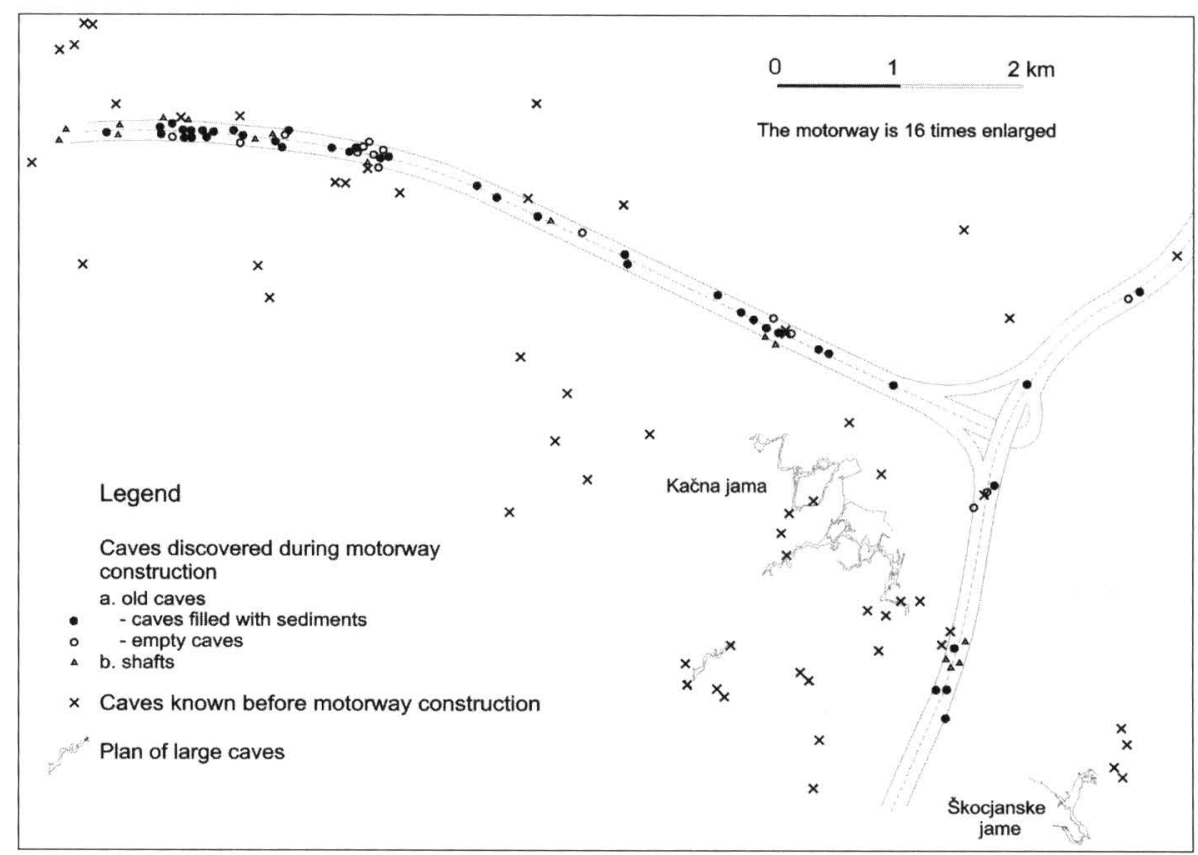

Fig.1 - Part of a motorway, with newly discovered caves

faster, unroofed caves on the karst surface resemble dolines, strings of dolines or oblong depressions.

Doline-like forms occur when the lowering surface cuts an old tunnel in a crosssection that is filled with alluvial deposits and flowstone, when reaches it at a single point, or when dolines develop in the cave alluvium that fills a larger uncovered passage. Strings of such shapes commonly reveal the shape and size of the remodelled cave. Oblong depressions develop from larger unroofed tunnels running parallel to the surface. Many of them represent an interweaving of various old forms, that is, caves and current karst formations, surface karst and epikarst. Fine-grained fill, which in this case is largely ancient cave alluvium, must also be removed from unroofed caves, and the caves must then be refilled with rocks and rubble. Otherwise, water could gradually wash away the alluvium, and silt would appear on the surface. Parts of these caves, or younger cavities that developed through them and are only exposed as the fill is excavated, can be also be sediment free and open (Fig. 3a: a doline with caves).

Relative to the aquifer development, caves can be divided into old caves through which waters percolated when the karst aquifer was enclosed, higher and covered with flysch, and shafts through which water percolates vertically from the permeable karst surface toward the underground water. The deepest shaft found so far measures $110 \mathrm{~m}$ in depth (Figs.3b, c). The old caves may be empty or filled with alluvium, and filled caves represent almost two thirds of those found. Many of the caves are opened during the digging of road cuttings and tunnels, and they include shafts or parts of old caves. They open under roads or in the road banks during construction. Cave 


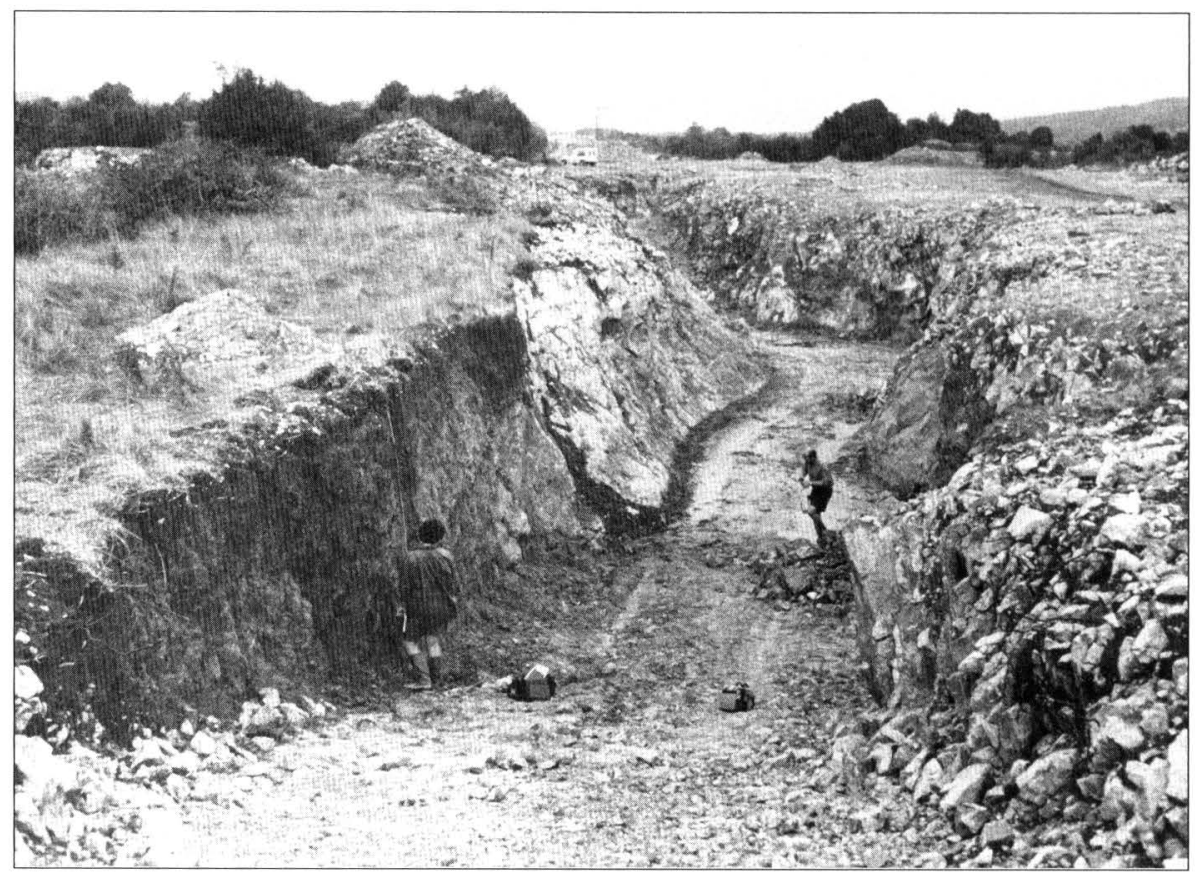

Fig. 2 - Unroofed cave

roofs commonly collapse due to blasting or other construction work nearby.

All of the caves are studied, plans are drawn and their form and rock relief are determined. Samples of alluvium are collected for palaeomagnetic and palynological research, and flowstone samples are collected for mineralogical research and dating. Additionally, attempts are made to discover the locations of inaccessible parts of the caves. The approach to preservation and treatment of caves depends on the individual caves and the conditions surrounding them, particularly the deformation of the rock. Thorough surveys, which always require extreme caution due to the possibility of rockfalls, have proven indispensable to the builders. Individual survey programmes are dictated by the forms of the caves themselves, which have been hollowed out in various ways beneath and beside the route corridors. Commonly only small entrances are open, and below them are caves that expand in width. Many cave roofs are thin and there is a danger of collapse during further construction or the later use of the roads (Figs.3d, e). As a rule, the builders reinforce the surface above such caves with concrete slabs. This, of course, is not possible with caves whose walls and ceilings have been fractured by blasting and where thicker roofs have collapsed (Fig.3f).

Cave roofs may also collapse during the use of large vibrating rollers for final compacting of ballast on a roadbed (Fig. $3 \mathrm{~g}$ ). A relatively large number of caves are also opened in the course of building embankments (Figs 3h, i). This shows that caves can quickly be concealed during blasting, as they either collapse or their entrances are covered with rock and rubble. However, such features can be preserved with slower manual digging. 


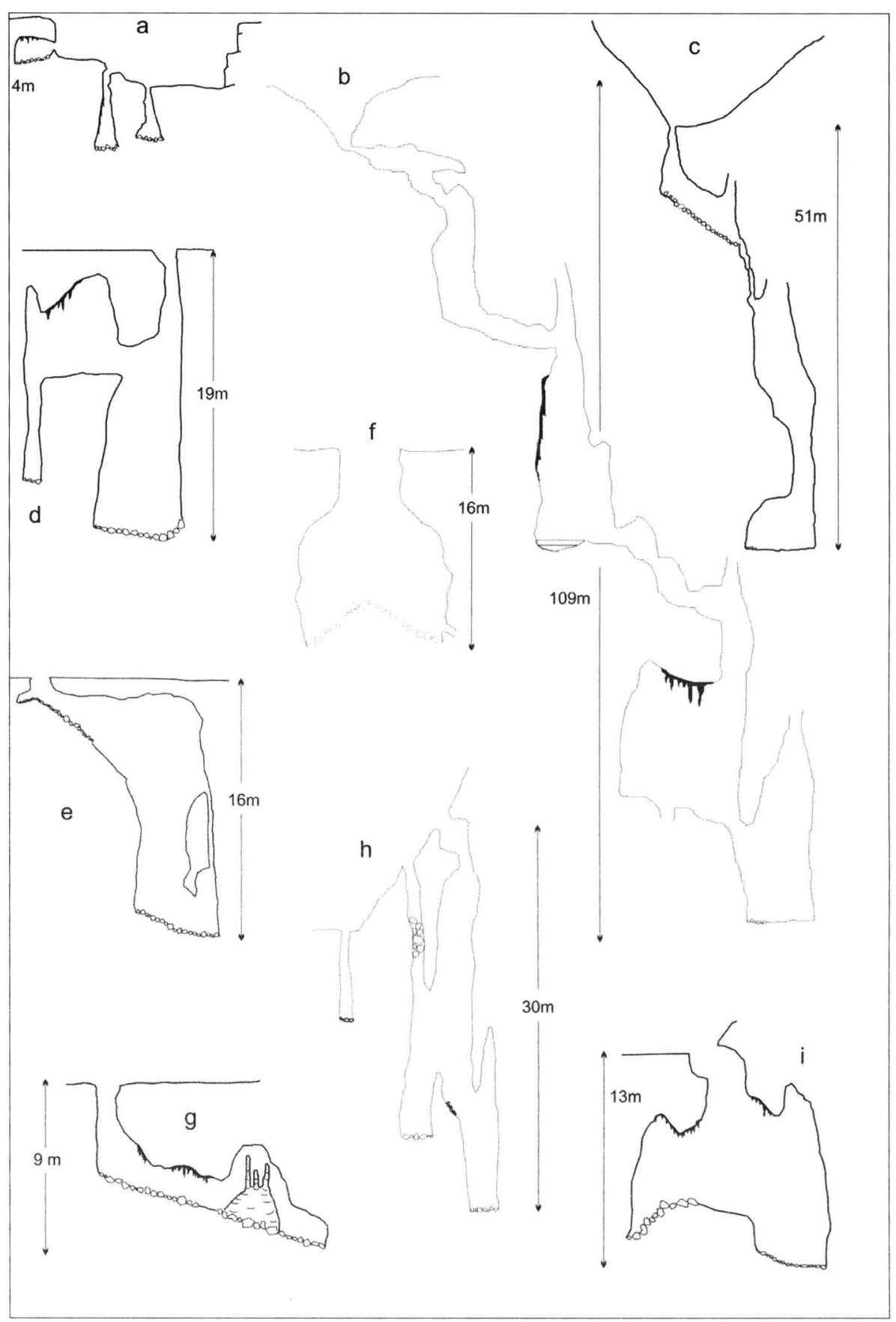

Fig.3 - Cross-section of newly discovered caves 


\section{The preservation of caves and new knowledge about the development of karst gained during past motorway construction}

As many caves as possible were preserved. Shafts were the easiest type to preserve, since their relatively smaller entrances can simply be closed with concrete slabs. In similar fashion it was possible to preserve old caves whose walls and ceilings were solid. However, caves that were opened by blasting and which were in perforated rock had to be reblasted and filled in. Caves split by road cuttings, whose entrances were in the cutting sides were sealed off with rock walls. The cave walls and ceilings were highly fractured and therefore they were unsafe for further visiting. Furthermore, water could carry clay from alluvium-filled caves and deposit it on the road. One well-preserved cave was left unsealed, for viewing by visitors crossing the border with Italy. The most interesting and well-preserved caves were protected completely, even though they are now under the motorway. These are accessible through concrete pipes closed with locked grids beside the road.

The consequences of various types of blasting in caves have also been studied, and the information gained will help in future construction and the preservation of karst phenomena.

Unroofed caves are a distinctive and common karst form. Today, these significant karst surface features represent a familiar phenomenon, but they had not been studied thoroughly before the construction of the motorway across Kras. Subsequently great attention has been devoted to unroofed caves, since the incidence of this phenomenon turned out to be far higher than previously expected. A number of articles on unroofed caves and the construction of new motorways are now available (Knez and Sebela, 1994; Šebela and Mihevc, 1995; Slabe, 1996, 1997a, 1997b, 1998; Mihevc and Zupan Hajna, 1996; Mihevc, 1996; Kogovšek, Slabe and Šebela, 1997; Mihevc, Slabe and Šebela, 1998; Šbela, Mihevc and Slabe, 1999; Knez and Slabe, 1999). Unroofed caves are also an important part of the epikarst and provide an outstanding indication of the development history of the karst aquifer.

Many of the caves were filled with alluvial sediments. In most cases, these represented inundations of fine-grained flysch alluvium with intervening layers of gravel. Samples of alluvial deposits were taken from caves at Kozina and Divača for palaeomagnetic analysis, which confirmed that they pre-dated the end of the Olduvai chron. The conclusion is that the caves were formed before the Messinian phase. To a large extent they were filled with alluvial sediment after the refilling of the Mediterranean basin with water approximately 5.2 million years ago (Bosak et al., 2000), when the groundwater level in aquifers around the Mediterranean Sea rose to a high level relatively rapidly. The study examined evidence of the oldest preserved periods of karstification in Kras - not counting palaeokarst, of course - and established that the oldest caves in Kras are much older than karstologists previously supposed. In pockets of palaeokarst confirmed as dating from the Early and Late Cretaceous periods, the remains of dinosaurs and numerous other animals have been found.

The karst surface and epikarst that developed over the traces of older periods of karst development are typically formed on different bedrock. On Cretaceous limestone, karren commonly occur with distinct subterranean fissures below them. On Paleogene limestone, however, the surface is more smoothly rounded and in some places covered with rubble that originated due to surface disintegration during the 
Pleistocene Epoch, and the rock, although most commonly more densely fractured, is criss-crossed with fewer distinct fissures. Some of these caves are also rubblefilled.

\section{Conclusions}

The involvement of karstologists with all stages of motorway construction in karst regions, that is, during the entire process of encroaching on the sensitive karst landscape, is very useful. In this way the natural heritage can be preserved and basic knowledge about the origin and development of the karst, and about road building in such regions, is broadened. There are many different types of karst, and each demands a unique approach. Therefore, there must be regular cooperation with road builders in every case. In Slovenia during the past ten years this requirement has been very much recognized, and the level of cooperation between planners, road builders and karstologists now serves as a model for the planning and execution of various construction projects in karst regions.

In Slovenia's karst, which along with its many and diverse landforms is also characterized by active tectonics and lithostratigraphical diversity, caves are difficult to locate in advance. As a general rule, areas of contact between flysch and limestone are more heavily pierced by cavities. On the other hand, unroofed caves are a distinctive and increasingly readable feature of the karst surface. The degree of perforation is therefore determined primarily on the basis of a thorough knowledge of the karst, along with meticulous work during road planning and construction. The results gained are also useful in planning other construction projects in karst regions.

\section{REFERENCES}

BOSAK P., KNEZ M., OTRUBOVA D., PRUNER P., SLABE T. and VENDOHOVA D. 2000. Paleomagnetic Research of a Fossil Cave during Highway Construction at Kozina (Slovenia). Acta Carsologica 29/2: 15-33.

KNEZ M. and SEBELA S. 1994. Novo odkriti kraški pojavi na trasi avtomobilske ceste pri Divači. Naše jame, 36: 102.

KNEZ M., T. SLABE 1999. Unroofed caves and recognizing them in karst relief (Discovered during expressway construction at Kozina, southern Slovenia). Acta Carsologica 28/2: $103-112$.

KNEZ M. and SLABE T. 2001. Unroofed Caves Are an Important Feature of Karst Surfaces: Examples from the Classical Karst. Zeitschrif für Geomorphologie (accepted).

KOGOVSEK J., SLABE T. and SEBELA S. 1997. Motorways in Karst (Slovenia). Proceedings and a Fieldtrip Excursion Guide, $48^{\text {th }}$ Highway Geology Symposium, $49-55$.

KRANJC A. (Ed.) 1997. Slovene Classical Karst. ZRC SAZU, Ljubljana.

KRANJC A. (Ed.) 1999. Kras. Pokrajina-življenje-ljudje. ZRC SAZU, Ljubljana.

MIHEVC A. 1996. The cave Brezstropa jama near Povir. Naše jame 38: 65-75.

MIHEVC A. and ZUPAN HAJNA N. 1996. Clastic sediments from dolines and caves found during the construction of the expressway near Divača, on the Classical Karst. Acta Carsologica 25: 169-191.

MIHEVC A., SLABE T. and ŠEBELA S. 1998. Denuded caves. Acta Carsologica 27/1: 165-174. 
SLABE T. 1996. Karst features in the expressway section between Čebulovica and Dane. Acta Carsologica 13: 221-240.

SLABE T. 1997a. Karst features discovered during expressway construction in Slovenia. Environmental Geology 32/3: 186-190.

SLABE T. 1997b. The caves in the expressway Dane-Fernetiči. Acta Carsologica 26/2: 361-372.

SLABE T. 1998. Karst features discovered during expressway construction between Divača and Kozina. Acta Carsologica 27/2: 105-113.

ŠEBELA S. and A. MIHEVC 1995. The problems of construction on karst - the examples from Slovenia: 475 - 479. In: Beck B. F. and Pearson F. M. (Eds), Karst geohazards, engineering and environmental problems in karst terrain. Proceedings of the Fifth Multidisciplinary Conference on Dolines and the Engineering and Environmental Impacts on Karst.

ŠEBELA S., MIHEVC A. and SLABE T. 1999. The vulnerability map of karst along highways in Slovenia. 419-422. In: Beck B.F., Pettit A.J. and Herring J.G. (Eds), Hydrogeology and engineering geology of dolines and karst -1999 . Proceedings of the Seventh Multidisciplinary Conference on Dolines and the Engineering and Environmental Impacts on Karst. 